$\xi=-$ 国

\title{
The development of post traumatic stress disorder among secondary school students in borno state Nigeria: a systematic review
}

\author{
Zainudin Abu Bakar ${ }^{1 *}$, Darma Kabiru Rabiu ${ }^{1}$ \\ ${ }^{1}$ School of Education, Faculty of Social Science and Humanities, Universiti Teknologi Malaysia \\ *Corresponding author E-mail: p-zain@utm.my
}

\begin{abstract}
Insurgency has long been rooted in the Nigerian society. It affected deeply in the daily activities of the country. Thousands of people including school children have been maimed, displaced, orphaned and killed in Borno and entire North Eastern Nigeria and some other part of North Western Nigeria especially in the state of Kano because of the insurgency. The Boko Haram movement for example have caused enormous chaos within the society especially the school children. The movement have targeted civilian populations irrespective of gender, tribal and religious inclination among people and, the merciless attack and bombings carried out by them including abduction and kidnapping of female students have caused destruction of the school facilities and the well-being of the society. A continuous exposure to such stress created by war resulted the development various difficulties such as Post-Traumatic Stress Disorder among school children. A systematic review was used to critically analyzed the impact of the insurgency in the society based on several related studies. The effect of the insurgency on the society was then highlighted which tells the story of the educational difficulties.
\end{abstract}

Keywords: War, Insurgency, Educational Difficulties, Secondary Students, Post-Traumatic Stress Disorder, Nigeria.

\section{Introduction}

Armed conflict, war or insurgency affecting civilian populations has become increasingly common toward the end of the twentieth century [1] in certain part of the world, especially in third world countries where there is high level of illiteracy, poor standard of leaving among the teeming populace that made it very difficult to cater for their basic necessities of life (food, clothing housing and education). The corresponding chaos places victims, the children and youth at significant risk, often exposing them to equal or greater psychological stress and trauma as compared to adults [1]. The traumatic experiences affect their success in school. It also cause severe physical or psychological trauma, malnutrition, disease, and decreased access to health services [2].

While physical morbidity may be similar to that in adults, children's psychological response to trauma may be quite different from adults' as a result of their rapidly changing developmental levels, limited coping styles, and inability to seek services [3]. Children's manifestation of trauma-related symptoms is different from adults and these symptoms are more likely to change from time [4]. The majority of studies conducted in this field tried to explore certain physical and psychological ill-health factors associated with conflicts on Children and women because they are the most victims.

There were plethoras of researchers conducted either in the form of quantitative, qualitative methods, explaining, interpreting, assessing, analyzing and describing the impact on war for causing psychological or emotional trauma among children and women as well as their psychological reaction to wartime stress, dating from the Second World War [5, 6]. A historical survey demonstrates that, even from the beginning of antiquity or ancient time psychological responses to mass violence have always been the source of scientific interest $[7,8,9,10]$.

Research showed that children living in war zones are at high risk of developing types of psychopathology, predominantly PostTraumatic Stress Disorders (PTSD) [11, 12]. Another essential point is that mass violence is the cause of severe psychological traumatic disorders [13]. This stress and fear that came into existence on the mind of teachers, students/pupils and educational administrators/supervisors as a result of schools attack prompted them to develop new behaviors or to modify existing patterns of behavior such as skipping work and school, running or weaving through parking lots, cancelling outdoor activities, and avoiding shopping centers as witnessed during the Beltway Sniper Attacks $[14,15]$. This paper tried to address the development of psychological trauma among secondary school children caused by the war experiences. The finding will be derived through systematic analysis from several of previous related studies.

\section{Methodology}

To gather relevant information on this study, online data bases such as Science Direct, Taylor and Francis, Emerald, Willey, Sage Journal, Springer link, JSTOR and Google Scholar were used in data searching the key words of Boko Haram, insurgency, conflict, war rebellion, and armed conflict were paired with the terms such as school attacked, psychological trauma, emotional trauma, psychological problems, physical problem and Post Traumatic Stress Disorder (PTDS).

However this study focused on the influence of Boko Haram conflict in causing psychological trauma among Secondary School 
Students of Borno states, Nigeria. Based on this meta-analysis all the articles retrieved were further examined and scrutinized diligently and manually in order to determine the articles related to this systematic review. The exploration activities were guided by PRISMA Statement which consists of a 27 -item checklist and a four-phase flow diagram to review related literatures systematically. The Prisma Diagram Generator was also utilised to generate the process of scrutinising of the articles. Out of this, the issues being discussed by the articles were presented.

There are total numbers of 95 articles which fulfilled the criteria: (1) the studies involve both the influence of Boko Haram conflict and various other conflicts that took place around the globe and their impact on educational development. (2) The studies either discuss the physical or psychological impact of war on education of either primary, secondary or tertiary institutions were adopted. (3) The studies either discuss it impact on students or their teachers were employed for this meta-analysis. Among the articles, 36 studies discussed the impact of Boko Haram on educational development of Borno and some other parts of North Eastern Nigeria that were seriously affected by Boko Haram activities, most of these studies conducted within the Nigerian context were somehow not psychological in nature compared to 59 studies conducted in different part of the globe especially Palestine, Sudan, Rwanda, Burundi, Bosnia, Egypt and Israel that were purely psychological and very scientific in nature.

\section{Results and discussion}

It appeared that scientific reports about the psychological effects of war among civilian populations and the provision of mental health services have increased in recent years since the Gulf War and the conflict in former Yugoslavia $[16,17,18,19,20,21,22$, $23,24,25,26,27]$. More recent reports have examined the impact of armed conflict, insurgency and war on children from many regions including: Africa [3, 28, 29], South Africa [30, 31, 32, 32], the Balkans [34], the Middle East [18, 26, 35, 36], and Southeast Asia [37, 38, 39, 40] Afghanistan [41], Palestine [42, 43], Lebanon [44], and Iraq [45].

Further analysis have highlighted that among the 95 articles reviewed, 36 articles as serially arrange examine and discuss critically the impact of Boko Haram on the entire educational activities of Borno state and some part of neighbouring states especially Yobe and Adamawa that were seriously affected by the Boko
Haram insurgency. The results can be briefly summarized as follow:

- Some of the articles explained clearly how the Boko Haram affect school enrolment figure negatively more especially in Primary and Post primary schools in Borno, Adamawa, Yobe and entire North Eastern.

- Few articles at least 3 out of 35 explained roles of Boko Haram in devastating of Business education in most of the institutions of higher learning in Borno state. The activities of Boko Haram brought about destruction of economic activities which led to the closure of so many small scale industries. This affects the development of Business education because students of Business education or entrepreneurship education have no place to go for attachment which is the basic requirement for graduation for students of entrepreneurships in Nigeria.

- Most of these studies focused on Girl child education, attacks and destruction of schools that affect school attendance and threatening the life of students and teachers that force many teachers to move into a peaceful areas and high cost of educational management that result in increasing the huge expenditure on government to effectively renovate the existing schools destroyed by Boko Haram. And lastly

- Very few studies focused on psychological or emotional aspect as found in (items 7, 8,9,10 and 15) and they do not fully discussed the impact of psychological trauma on students. The main focused on these articles is:

i. Risk of drinking//hazardous drinking as a result of exposure to violence among college students.

ii. The prevalence of depression, psychological distress, PTSD and evidence of socioeconomic distress that affect students' academic performances.

iii. Students' response toward exposure to traumatic events.

Below is the analysis of the articles generated by using the Prisma Generator in regards to inclusion and exclusion of articles among Secondary School Students of Borno State, Nigeria.
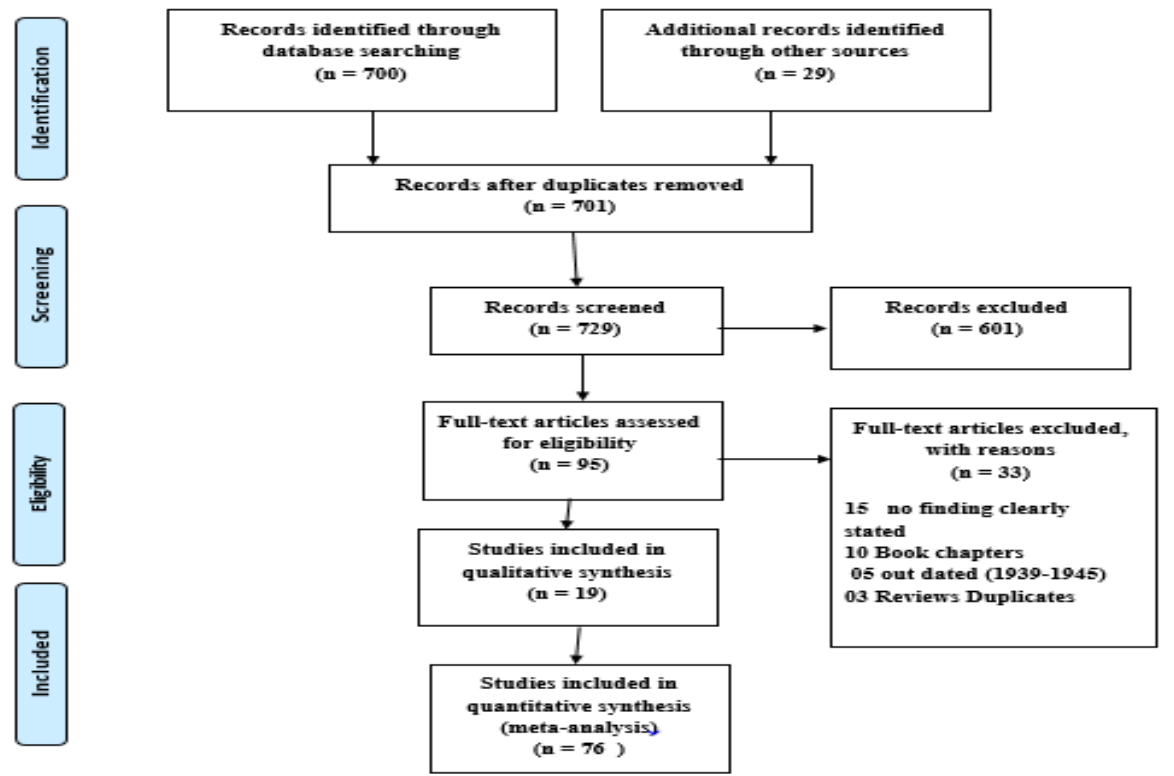


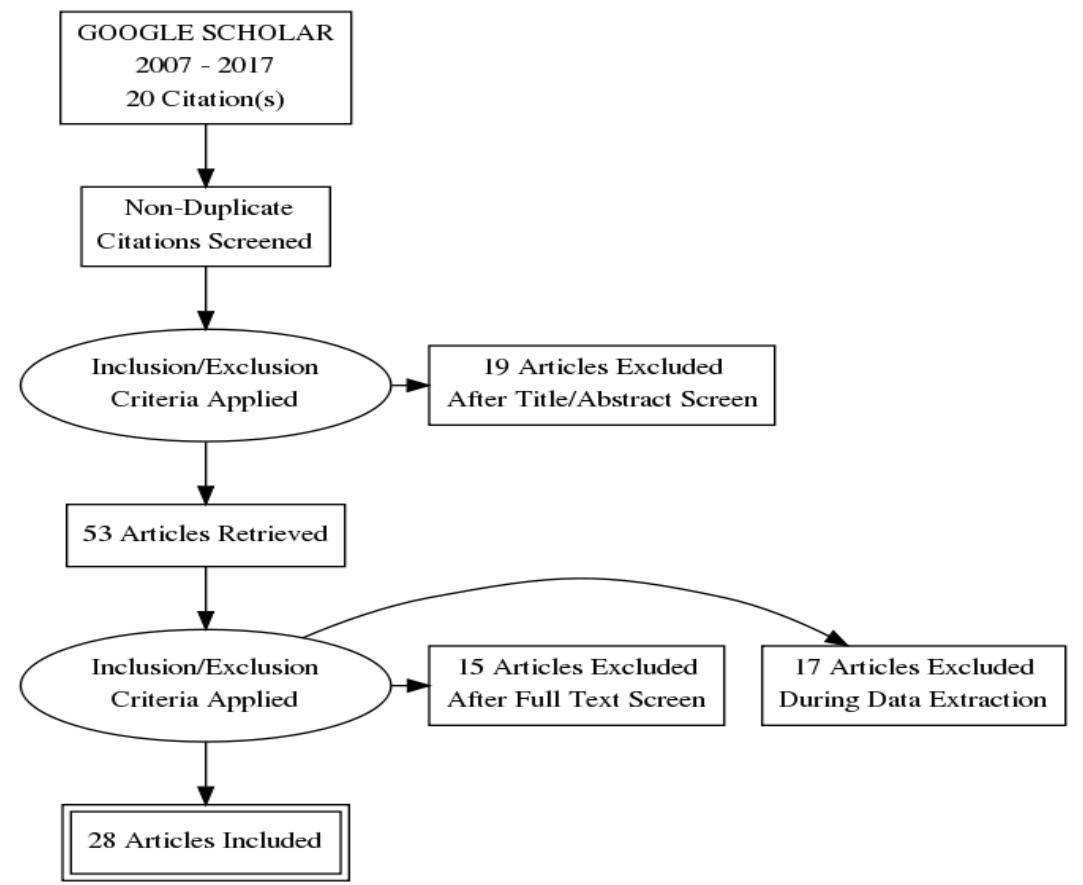

With regard to the next articles ranging from the serials (No 3795) focused to examine the prevalence of conflict/armed conflict/political violence outside Nigeria especially in the third world countries that witnessed long -standing political instability and ethnic conflict such as Palestine, Lebanon, Iraq, Bosnia, Democratic Republic of the Congo, Burundi, Rwanda, Liberia, Sierra Leone and South Africa. The articles focuses on these areas are in quantitative forms and research based papers addressing the issue of psychological trauma, PTSD and students exposure to war atrocities clearly. The findings of these articles concern on the following issues:

- Most of these articles explained the concept of PTSD, Psychological trauma with its associated problems such as depression, aggressive behaviour, sleeping difficulty, neurotic symptoms, summarization, hostility, and paranoid ideation symptoms among students irrespective of age, gender and lev$\mathrm{el}$ of education. This is why there were more researchers in primary schools pupils ranging between the ages of 06-12 years of age averagely.

- The researchers conducted mostly addressed students exposure to traumatic events such as beaten by armed forces, witnessed the murder, threaten with death, raping sexual assault and various traumatic events exposed upon the individual students as the opponent or in an attempt to make them fearless, courageous and bravery.

- There was strong participation or enforcement of young adolescents to serve as fighters.

\section{Discussion}

Boko Haram is a violent sect that traces its historical genesis in the city of Maiduguri the present capital of Borno state, Nigeria in 2002 under the leadership of Uztaz Muhammad Yusuf. At its earlier stage, the sect focused mainly on preaching against mismanagement of public fund by the Nigerian Politician, Military officers, Ministers, Federal and State Directors, commissioners, state and Federal permanent secretaries and other civil servants that embezzled the public fund which artificially forced many people more especially the teeming populace of rural areas of Nigeria to remain in abject poverty, with little or no means of decent leaving with modern amenities such as electricity, good water supply, medical and health facilities, road communication network and good housing.

The rural dwellers prepare to send their children from the age of six onward or even below in large numbers to urban areas to serve as "Almajiri" The term Almajiri is a Hausa word for a pupil or student. The word is derived from the Arabic term al-muhajir, meaning the migrant who serve as itinerant student/pupil to learn and memorize the holy Quran in urban areas [46]. This tends to have the negative and devastating effect on the psychosociological well-being of these "Almajirai," because they lack parental care and affection that negatively affect their personality development These "Almajirai" they normally end up becoming either street beggar leaving in poverty or hooligan, thugs and ruffians. The Boko Haram sect gained huge support from these "Almajirai, in Borno state and all the areas in the North Eastern state that were seriously devastated by Boko Haram sect particularly Yobe and Adamawa. Onochie [47] found that "Almajiri and Boko Haram are now like primary pupils graduating into secondary school. The two are inseparable and Boko Haram cannot exist without almajiri. If there is any difference between almajiri and Boko Haram, it should be a matter of semantics." The linked between Boko Haram activities in Nigeria and the support they gained from "Almajiri" has been supported by numerous researchers such as that of $[47,48,49,50,51]$.

The Boko Haram sect used poor socio-economic conditions as a chance to attract the attention of youth leaving in poverty to join the sect in large number. More importantly, poverty in Nigeria characterized by hunger, homelessness, diseases, malnutrition, high child mortality rate, family disintegration, unemployment, human trafficking, child labour, kidnapping, killing, sexual assault, drug abuse, prostitution, and high mortality rate. The rate of poverty in Nigeria more especially in the North Eastern part where the Boko Haram emerged continued to persist with those living below $\$ 1$ per day are 61.2 per cents; the Gini-coefficient measure of income inequality rose from 0.429 in 2004 to 0.447 in 2010, whereas Nigerians living in extreme poverty rose from 6.2 per cents in 1980 to 38.7 per cents in 2010 , and this co-related with early inception of Boko Haram crises [52].

There is significant co- relation between poverty and outbreak of Boko Haram crises in Borno state. Also, Olojo [53] argue that one of the key factors that encourages the youth to join violent extremist ideology; recruitment and support for Boko Haram is economic deprivation. Majority of the youth were living in abject poverty 
and cannot afford at least three square meal per day; no decent and luxury living with modern amenities that help them to feel comfort and psychologically well-being and balance especially in rural areas Several scholars believed that poverty and longstanding economic disparities in the northeast part of the country made the youth join the sect.

Similarly, Adesoji [54] stresses that, in Nigeria, the marginalization and imbalance distribution or implementation of the resources made some radicalized scholars to preach against the government and democratic setting, which later gave birth to the present Boko Haram insurgency that causes serious havoc to the entire education system of Borno state, Nigeria. The country was ranked 153th out of 177 poor economic countries on the human development index (2008), despite its rich cultural endowment and abundant human and natural resources. The increasing rate of unemployed youth in the region, which was economically deprived, mostly was the recruiting target of Boko Haram.

The insurgents believed that it is the Western education system that gave the chance of politicians and others state civil servants to betray the position of trust and remained as looters to state treasury. It was against this development that the sect considered Western education as unlawful or sin henceforth devised various strategies of attacking schools and facilities provided to facilitate teaching and learning process, teachers, students and educational administrators, kidnapping and abduction of girls as well as sexual abuse and force enlistment of young people as members of Boko Haram insurgents. All these combined together to stand as the menace against Borno state educational system and have threatened the psychological well-being of secondary school students of Borno state Nigeria.

Education in Borno state both at primary level, secondary and tertiary institution levels is detrimentally affected with the challenges of Boko Haram insurgency. This is because the insurgency has led to the destruction of many schools more especially primary and secondary schools which have made the states to close down school and colleges for a long period of time. It has affected education in the Borno state - low school enrolment, especially for girls as well as high number of out of school children [55].

According to documents released by the Federal Ministry of Education in 2013, depicting the state of education in North Eastern Nigeria opined that schools in the areas more especially those that are facing the threat of attack from the Boko Haram insurgents witnessed poor students' enrolment. The populations of students that are attending schools as well as that of the new intakes at the beginning of new term or session reduce drastically for fear of attacks and kidnapping by the insurgents. In Government Girl Secondary School Chibok that witnessed that devastating effect of the kidnapping of 276 secondary schools students recorded poor enrolment figure since then (Aljazeera, the BBC and the Guardian 2014)

The required number of students to be enrolled in 2017 into Junior Secondary school is $\mathbf{2 7 5}$ girls but only 79 girls were available and successfully enrolled. The trend of admission of newly students goes the same with that of Secondary school for boys in Borno state but only with little or insignificant differences were found The very recent attacks on Government Science and Technical College Dapchi in yobe on Monday, 19 February 2018 were by nearly 105 girls were kidnapped by Boko Haram members result in the indefinite close down of the school and all the schools nearby. The end result of the attacks will likely to affect students' intake and admission negatively.

The Boko Haram crisis served as a serious constraint to education more specifically on girl-child education, low record of attendance and poor enrollment figure more especially in primary and secondary school in the state. Children's educational attainment is particularly compromised by exposure to violence. The effect of war on young people's educational attainment has been documented in several studies such as $[56,57,58,59,60,61,62,63$, 64, 65, 66, 67, 68, 69, 70, 71, 72, 73, 74, 75, 76, 77, 78, 79]. An official in the Ministry of Education in Borno state reportedly stated that "around 15,000 children in Borno state have stopped attending classes" following the increased insecurity in the state, including the attacks on schools. A teacher from one village in northern Borno state, hiding in Maiduguri in fear for his safety, told Amnesty International that there is no opportunity for children in the village to continue their education after the schools were forced to close. He said, "None of the children go to school now. Those who were taking exams had to hide their school uniforms in a plastic bag before they leave home. Boko Haram even tore the uniforms of students who travel to Maiduguri to attend school from the village. They warned all the students to stop attending schools, except Islamic schools."

Attacks on schools carried out by Boko Haram insurgent negatively affect the teachers' willingness to accept responsibilities more especially in areas that were seriously devastated by Boko Harm activities. The attacks led many teachers to stop coming to schools by moving out from the area or even the country [80. In most of the schools such as Government Secondary School Chiboc, Government Secondary School Mafomi, Government Secondary School Lamosola and many others schools including primary schools in most vulnerable areas or local government that were partially captured by Boko Haram because of threat of attacks and continuing assassinations of teachers emanating from Boko Haram insurgents forced many teachers to lost interest in teaching as a profession. These negatively affect the teacher morale, interest, ability to teach effectively, concentration and frame of mind for teaching. Insecurity generated by Boko Haram insurgents affected the psychological and emotional well-being of teachers and thus in one way or the other affect the quality of education provided to the students [75].

According to Educational For All Global Monitoring Report, 2011(EFAGMR) [81] "Attacks on higher education and teacher training institutions may restrict research, teaching content and pedagogical training and cause drop out, distraction, demoralization and traumatisation of tertiary students and academics. This can in turn lead to restrictions on teacher content, knowledge and teacher quality". Teachers served as the backbone for the transformation of any society to advance stage of development. There are no any societies that reach certain high level of scientific and technological advancement without effective and productive teachers that transform the national curriculum from theory to practice. Teachers served as the instrumental figures for depicting the aims and objectives, yearning and aspiration and all that the societies are hope to become in future as scientifically plan and tailor with the educational curricular as a catalyst for their effective realization.

The attacks carried out by Boko Haram insurgents detrimentally affected both students and teachers. Michael Olukoya - speaking at a World Teachers' Day event in Ado Ekiti - said 308 Nigerian Union of Teachers (NUT) members had been killed in Borno state, 120 in Plateau, 75 in Adamawa, 63 in Kano, 25 in Kaduna, 18 in Yobe and two in Gombe . Since 2007 "there have been thousands of reported cases of students, teachers, professors, academics and other members of the educational community being taken prisoners, held in captivity, beaten, tortured, burnt alive, shot by rebels, armies and repressive regimes; imprisoned or raped by armed groups or forces in school or on their way to school" . But yet there is a paucity of study exploring the detrimental effect of Boko Haram on teachers in Borno state. The attacks carried out by Boko Haram on teachers in no small measure are likely to affect educational development in the following ways:

$$
\begin{aligned}
& \text { Longer-term disruption of attendance of } \\
& \text { teachers and staff } \\
& \text { and staff The permanent drop-out of teachers, students } \\
& \text { Lowering of the quality of teachers } \\
& \text { teachers, and staff by fear or trauma, reducing the quali- } \\
& \text { ty of education provision and students' ability to learn }
\end{aligned}
$$


- $\quad$ Falling recruitment of staff, leading to teacher shortages.

Boko Haram conflict like the other conflicts that took place in different parts of the world exposed students to the certain level of war atrocities. There were insufficient kinds of literatures exploring, analyzing and interpreting the psychological impact of Boko Haram, unlike others conflicts that took place in Palestine, Egypt, Rwanda, Burundi and Israel. The Boko Haram failed to discuss extensively the psychological implication of attacks on young children at primary schools and the few studies on secondary school students concern with the study of depression and hazardous alcoholism as the psychological aspect discussed by these studies. The studies were silent in explaining as well as exploring all the psychological problems that came into existence as the results of students exposure to violence such as revenge seeking, anxiety, depression, withdrawal, sleep disorder, fear and panic, poor school performance, absenteeism, withdrawal, truancy, school-phobia, lateness, unhealthy relationship with colleagues and teachers and involvement in criminal violence.

The exposure of children to traumatic events such as the loss of loved ones, displacement, a lack of food, displaced from home, stayed in IDP camps, parents disappeared or killed and the interruption of school associated with armed conflict has detrimental consequences for students' mental health and psychological wellbeing. People who were exposed to traumatic events subsequently experience a positive psychological change known as Posttraumatic growth (PTG) or Posttraumatic stress disorder (PTSD) [82] The exposures of students to these traumatic events as a result of Boko Haram conflict in Borno state, Nigeria are likely to affect their psychological and emotional well-being that may lead to persistent outbreak of psychological trauma, and PTSD as well as other psychological problems that affect student academic achievement.

Many studies conducted in various part of the globe that witnessed the long-standing conflict more especially ethno-religious conflict that aimed at ethnic extermination of a particular tribe or religious belief such as Rwanda, Burundi, Sudan, Palestine, Bosnia, Democratic Republic of Congo, Liberia, Sierra-Leone and Nigeria especially Northeastern part of the country are likely to have the prevailing cases of psychological trauma with it attendant problems. Studies have found that a child or an adult who has been exposed to traumatic events for a long period of time is in danger of developing more severe PTSD symptoms or psychological problems. This is in line with the finding of various authors such $[83,84,85]$ For instance, children in Lebanon who were exposed to shelling, death, and forced displacement were 1.7 times more likely to manifest regression, depression, and aggression than those who were not [86]. When the duration of trauma lasted more than one year, $73 \%$ of the children had PTSD symptoms compared to only 37\% when the duration of trauma was less than one year [88]. Moreover, research suggests that individuals who experience chronic trauma have lower rates of recovery from PTSD [4, 89, 90, 91].

\section{References}

[1] Stein B, Comer D, Gardner W \& Kelleher K (1999), Prospective study of displaced children's symptoms in wartime Bosnia. Social Psychiatry and Psychiatric Epidemiology 34(9), 464-469. https://doi.org/10.1007/s001270050221

[2] Martinez P \& Richters JE (1993), The NIMH community violence project. II. Children's distress symptoms associated with violence exposure. Special issue. Children and violence. Psychiatry Interpers Biol Proc 56, 22-35.

[3] Magwaza AS \& Killian BJ, et al (1993), The e€ects of chronic violence on preschool children living in South African townships.Special section. Children and war. Child Abuse Neglect 17, $795 \pm 803$

[4] Terr L (1991), Childhood trauma: An outline and overview. American Journal of Psychiatry 148, 10-20.
[5] Bodman F (1941), War conditions and the mental health of thechild BMJ 2, 286 \pm 288

[6] Glover E (1942), Notes on the psychological effects of war conditions on the civilian population. III. The blitz. Int J Psycho-analysis 29, 17-37

[7] Ben-Ezra M (2004), Trauma in antiquity: 4000 year old posttraumatic reactions? Stress andHealth 20,121-125.

[8] Ben-Ezra M (2010), Traumatic reactions from antiquity to the 16th Century:Was there a common denomina- tor? Stress and Health, DOI: 10.1002/smi.1338. Ben-Ezra,

[9] Birmes P, Hatton L, Brunet A \& Schmitt L (2003), Early historical literature for posttraumatic symptom- atology. Stress and Health 19,17-26.

[10] Birmes P, Bui E, Klein R, Billard J, Schmitt L \& Allenou C (2010), Psychotraumatology in antiq- uity. Stress and Health 26, 21-31.

[11] Husain S, Nair J, Holcomb W, Reid J, Holcomb W, Reid J, Vargas V \& Nair S (1998), Stress reactions of children and adolescents in war and siege conditions. American Journal Psychiatry 155(12), 1718-1719.

[12] Mohlen H, Parzer P, Resch F \& Brunner R (2005), Psychosocial support for war-traumatized child and adolescent refugees: Evaluation of a short-term treatment program. Australian \& New Zealand Journal of Psychiatry 39(1-2), 81-87.

[13] Roth G, Ekblad S \& Agren H (2006), A longitudinal study of PTSD in a sample of adult mass-evacuated Kosovars, some of whom returned to their home country. European Psychiatry 21, 152-159. Ruggiero

[14] Coppola DP (2004), Gripped by fear: Public risk (mis)perception and the Washington, DC sniper. Disaster Prevention and Management 14(1), 32-54.

[15] Mitchell A (2007), Social impacts of fear: An examination of the 2002 Washington, DC sniper shootings. Unpublished working paper, Colorado State University, Boulder, CO. http://www.colorado.edu/hazards/awards/papercompetition/Mitchell_ImpactsOfFear.pdf

[16] Al-Eissa YA (1995), The impact of the gulf armed conflict on the health and behaviour of Kuwaitichildren. Social Science and Medicine 41, 1033-1037.

[17] Ben-Zur H \& Zeidner M (1991), Anxiety and bodily symptoms under the threat of missile attacks:The Israeli scene. Anxiety Research 4, 79-95.

[18] Klingman A (1992), Stress reaction of Israeli youth during the Gulfwar: a quantitative study. Prof Psychol Res Pract 23, 521 5527

[19] Klingman A (1992), Stress reactions of Israeli youth during the Gulf war: A quantitative study.

[20] Professional Psychology: Research and Practice 23, 521-527.

[21] Klingman A (1992), School psychology services: Community based, first-order crisis interventionduring the Gulf war. Psychology in the Schools 29, 376-384.

[22] Klingman A (1992). The contribution of school mental health services to community-wide emergency reorganization and management during the Gulf war. School Psychology International 13 , 195-206.

[23] Kuterovac G, Dyregrov A \& Stuvland R (1994), Children in war: A silent majority under stress.British Journal of Medical Psychology 67, 363-375.

[24] Llabre MM \& Hadi F (1994), Health-realted aspects of the gulf crisis experience of Kuwaiti boys and girls. Anxiety, Stress, and Coping 7, 217-228.

[25] Moore M \& Kramer D (1993), Value reflection in Israeli children's drawings during the Gulf War.Archivio di Psicologia Neurologia $54,3-12$.

[26] Nader K \& Pynoos RS, et al (1993), A preliminary study of PTSD and grief among the children of Kuwait following the Gulfcrisis. $\mathrm{Br}$ Clin Psychol 32, 407 \pm 416 .

[27] Zeidner M, Klingman A \& Itskowitz R (1993), Children's affective reactions and coping underthreat of missile attack: A semiprojective assessment procedure. Journal of Personality Assessment 60, 435457.

[28] Cliff J, Noormahomed AR (1993), The impact of war on children'shealth in Mozambique. Soc Sci Med 36, 843 \pm 848 .

[29] Hagengimana A, Hinton D, Bird B, Pollack M \& Pitman RK (2003) Somatic panic-attack equivalents in a community sample of Rwandan widows who survived the 1994 genocide. Psychiatry Research $117,1-9$.

[30] Dawes A (1990), The effects of political violence on children: A consideration of South Africa and related studies. International Journal of Psychology 25,13-31. 
[31] Dawes A \& De Villiers C (1987), Preparing children and their parents for prison: the wynberg seven. In D. Hanson (Ed.), Menta health in transition. Cape Town: OASSSA Second National Conference Proceedings.

[32] Dyregrov A, Gupta L, Gjestad R \& Mukanoheli E (2000), Trauma exposure and psychological reactions to genocide among Rwandan children. J trauma Stress 13(1), 3-21.

[33] Calhoun PS, Wiley M \& Beckham JC (2009), Self-reported health and physician diagnosed illnesses in women with posttraumatic stress disorder and major depressive disorder.Journal of Traumatic Stress 22(2), 122-130.

[34] Ajdukovic M (1998), Displaced adolescents in Croatia \pm sources ofstress and posttraumatic stress reaction. Adolescence 33: 209 \pm 217 .

[35] Abdelkhalek AM (1997), A survey of fears associated with Iraqi aggression among Kuwaiti children and adolescents \pm a facto-rial study 5.7 years after the Gulf War. Psychol Rep 81: 247 \pm 255

[36] Schwarzwald J \& Weisenberg M, et al (1993), Stress reaction of school-age children to the bombardment by SCUD missiles. JAbnorm Psychol 102, 404 \pm 410

[37] Clarke GN, Sack WH, et al (1993), Three forms of stress in Cambodian adolescent refugees. J Abnorm Child Psychol 21, 65 \pm 77 .

[38] Sack W, Clarke G \& Seeley J (1995), Posttraumatic stress disorder across two generations of Cambodian refugees. Journal of the American Academy of Child \& Adolescent Psychiatry 34(9), 11601166.

[39] Savin D \& Sack WH, et al (1996), The Khmer adolescent project III. A study of trauma from Thailand's site II refugee camp. $J$ AmAcad Child Adolesc Psychiatry 35, 384 \pm 391

[40] Realmuto G, Masten A, Carole L, Hubbard J, Groteluschen A \& Chhun B (1992), Adolescent survivors of massive childhood trauma in Cambodia: life events and current symptoms. Journal Traumatic Stress 5, 589-599.

[41] Mghir R, Freed W, Rashin A \& Katon W (1995), Depression and post traumatic stress disorder among a community sample of adolescent and young adult Afghan refugees. Journal of Nervous and Mental Disease 183, 24-30.

[42] Qouta S \& El-Sarraj E (2004), Prevalence of PTSD among Palestinian children in Gaza Strip. ArabPsyNet Journal 2, 8-13.

[43] Hawajri A (2003), Effectiveness of a suggested counseling program to alleviate trauma among the students of basic stage in Gaza Governorate. Unpublished master dissertation, Islamic University, Gaza, Palestine.

[44] Sibai A \& Sen K (2000),War and traumatic injury related disability: The need for rehabilitation in the after math of war in Lebanon (1999). This study was part of a larger study funded by the European Commission's INCO-DC Program (1996-1999) in Lebanon and Palestine. IC 18 CT 96 0036. It involved AUB Lebanon, INED France and Cambridge UK

[45] Ahmad A, Sofi M, Sundelin-Wahlsten V \& von Knorring A (2000) Post traumatic stress disorder in children after the military operation "Anfal" in Iraqi Kurdistan. Eur Child Adolesc Psychiatry 9 , 235-243.

[46] Khalid S (2006, May 7-11), State, economy and Almajirci system of education in Nigeria. Paper presented at the 1st African regional Consultative conference on the role Parliamentarians in the protection and development of Almajiri child. Arewa house, Kaduna, Nigeria, 1

[47] Onochie OE (2011 July 17), Boko Haram, An Advanced Almajiri. Sahara Reporters. Retrieved from http://saharareporters.com/2011/07/17/boko-haram-advanced-alma jiri

[48] Odoma SU (2014), Security misperceived in Nigeria. Ibadan: John Archivers

[49] Odoemelam CC, Kidafa I, Onyebuchi AC \& Agu OS (2014), Inbluence of the Boko Haram Security Threat in Nigeria on the Level of Interest in Mainstream Media News Among Postgraduate Students at University of Nigeria, Nsukka. Global Journal of Interdisciplinary Social Sciences 3(3), 77-84.

[50] Onwumere O (2015 February 4), Burden of the national almajiri education initiative. Daily Post (Nigeria). Retrieved from http://dailypost.ng/2015/02/04/odimegwu-on wumere-burdennational-almajiri-education-initiative/

[51] Abdulrafiu L (2009 December 27), Almajiri - Breeding of Future Terrorists. Citizens for Nigeria. Retrieved from http://www.citizensfornigeria.com/index.php/action/item/617almajiri-breeding-\%20of-future-terrorists/617-almajiri-breeding-offuture-terrorists
[52] National Bureau of Statistics NBS (2010 January 13), The Nigerian poverty profile, 2010 report. Contained in press briefing by the Statistician General of the Federation.Abuja: NBS, Government of Nigeria.

[53] Olojo A. Nigeria's Troubled North: Interrogating the Drivers of Public Support for Boko Haram. Retrieved. 2013.2014.http://www.icct.nl/download/file/ICCT-OlojoNigeriasTroubled-North-October-2013.

[54] Adesoji A (2010), The Boko Haram Uprising and Islamic Revivalism in Nigeria/Die Boko-Haram-Unruhen und die Wiederbelebung des Islam in Nigeria. Africa Spectrum 95-108.

[55] Bilyaminmu M, Baba I \& Suleiman I (2017), ANALYSIS OF THE IMPACT OF BOKO HARAM INSURGENCY ON EDUCATION IN ADAMAWA STATE, NIGERIA 5(6), 45-56.

[56] Ruguoyyatu AR (2013), Declining enrolment in primary education in Nigeria. Press Conference, March 11, Abuja: Minister of Education.

[57] Osunyikanmi AF (2008), "Gender Inequality in Nigeria Educationsector' African Journal of Stability and Development 2(2).

[58] Abdulrasheed O, Bello A \& Adaobi O (2014), Historical Analysis of Boko Haram Insurgency on Educational Management in Northern Nigeria, Global Journal of Arts Humanities and Social Sciences, published By European Centre for Research Training and Development UK (www.eajournals.org).

[59] Joda F \& Abdulrasheed O (2015), ' Effects of Insurgency on Girls Education in North-eastern Nigeria", European Journal of Educationand Development Psychology, UK 3(1), 44-50.

[60] Kudirat Initiative for Democracy KIND (2014), 'Pushing for safe education for Girls In Nigeria', Catapult, New York, NY 11201

[61] Abdullahi U, Atsua TG, Amuda BG \& Ago AH (2013), Impact of insecurity on school attendance of junior secondary school students in Maiduguri Metropolis, Borno State, Nigeria. Sokoto Educational Review 14(2), $76-82$.

[62] Fatima MJ \& Olowoselu A (2015), Effect of insurgency on girl education in North Eastern Nigeria: European Journal of Education and Development Psychology 3 (1), 44 - 50.

[63] Olowoselu A (2014), Historical analysis of Boko Haram insurgency on educational managementin Northern Nigeria. Global Journal of Arts, Humanities and Social Sciences 2 (10), 77-83

[64] Justino P (2014), Barriers to Education in Conflict-Affected Countries and Policy Opportunities ${ }^{`}$ Paper commissioned for Fixing the Broken Promises of Education for All: Findings from the Global Initiative on Out-of-School Children (UIS/UNICEF, 2014), Montreal: UNESCO Institute for Statistics (UIS). Retrieved from http://www.allinschool.org

[65] Shah S \& Scholz S (2013), Falling Through the Cracks: Barriers to Conflict Affected Malian Children's' Education. Retrieved from http://www.plan.ie

[66] Katz I, La Placa V \& Hunter S (2007), Barriers to Inclusion and Successful engagement of Parents in Mainstream Series. Retrieved from http://www.jrf.org.uk/bookshop

[67] Plan (2013), Girls' Education under Attack. Retrieved from http://www.plan-uk.org

[68] Ovuorie T (2015), 'Northern States have Nigeria's worst girl-child education - Report. Premium Times October 13,

[69] National Population Commission (2014), Basic Education Profile for Northeast Nigeria (Adamawa, Bauchi, Borno, Gombe, Taraba, and Yobe States)

[70] Ogbebo W (2014), 'Insecurity Threatens Girl-child Education in Nigeria - UNICEF' Leadership Newspaper, — Jun 15, 2014 4:43 $\mathrm{pm}$

[71] NEMA (2014), National Emergency Management Agency. Abuja, Nigeria.

[72] Olugbode M (2015), Children Now Live in Fear in Northeastern Nigeria. ThisDayLive. Wednesday 02 September,

[73] Obiajuru N (2015), 2,000 Primary School Pupils Study in 2 Classrooms In Bauchi. Source: Naij.com newsNANPM News

[74] BSMOE (2015), Borno State Ministry of Education. Maiduguri

[75] Amnesty International (2014), Human Rights Condition in Northeastern Nigeria Amnesty International

[76] Poirier T (2012), "The Effects of Armed Conflict on Schooling in Sub-Saharan Africa." International Journal of Educational Development 32, 341-51.

[77] Akresh R \& de Walque D (2006), “Armed Conflict and Schooling: Evidence from the 1994 Rwandan Genocide." HiCN Working Paper (47), University of Sussex, Brighton 
[78] Dabalen AL \& Paul S (2012), "Estimating the Causal Effects of Conflict on Education in Co^te D'Ivoire." Policy Research Working Paper 6077, World Bank, Washington DC.

[79] Davies \& Lynn (2010), "The Different Faces of Education in Conflict." Development 53(4), 491-97.

[80] Brenda o (2010),'. The long term impact of attacks on education systems, development and fragility and the implications for policy responses. Education for All Global Monitoring Report.

[81] Education for All Global Monitoring Report (2011), The hidden crisis: Armed Conflict and Education. United Nations Education Scientific and Cultural Organisation.

[82] Helgeson V, Reynolds K \& Tomich P (2006), A meta-analytic review of benefit finding and growth. Journal of Consulting and Clinical Psychology 74(5), 797

[83] Kaysen D, Resick P \& Wise D (2003), Living in danger, the impact of chronic traumatization and the traumatic context on post traumatic stress disorder. Journal of Trauma, Violence, \& Abuse $4(3), 247-264$

[84] Yule W (2001), Posttraumatic stress disorder in the general population and in children. Journal of Clinical Psychiatry 62(17), 23-28.

[85] Melhem N, Day N, Day R, Reynolds C \& Brent D (2004), Traumatic grief among adolescents exposed to a peer's suicide. American Journal Psychiatry 161, 1411-1416

[86] Chimienti G, Nasr J \& Khalifeh I (1991), Children's reactions to war-related stress: Affective symptoms and behavior problems. Social Psychological Psychiatry Epidemiology 24, 282-287.

[87] Sawyer S \& Patton G (n.d.), Why Adolescent Health Matters 110 127.

[88] Wolfe D, Sas L \& Wekerle C (1994), Factors associated with the development of post-traumatic stress disorder among child victims of sexual abuse. Child Abuse \& Neglect 18, 37-50.

[89] Famularo R, Fenton T, Augustyn, M.,\& Zuckerman, B. (1996), Persistence of pediatric posttraumatic stress after two years. Child Abuse Negl 20,1245-1248.

[90] Green B (1985), Children traumatized by physical abuse. In:Posttraumatic Stress Disorder in Children, Eth S, Pynoos RS, eds. Washington, DC: American Psychiatric Press 133-154.

[91] Altawil M, Nel PW, Asker A, Samara M \& Harrold D (2008), The effects of chronic war trauma among Palestinian children. Children: The Invisible Victims of War - An Interdisciplinary Study 1-21. Retrieved from http://eprints.kingston.ac.uk/24132/. 